\title{
Implementation of E-Government Working to Improve Effectiveness
}

\author{
Retno Fuji Oktaviani, Dewi PuspaningtyasFaeni, Ratih PuspitaningtyasFaeni, Rinny \\ Meidiyustiani
}

\begin{abstract}
E-government is a system application that can be used for transaction processing and monitoring the creation of documents that exist in government, especially in the field of community service. E-Government is one of the application services of the Smart City program run by the central government. Jakarta Smart City is an attempt by the government to develop a system of government that is effective, efficient, and transparent to optimize the use of Information Technology systems. E-Government is now applied in several villages. This type of research used by the authors in this research is descriptive qualitative. Data collection technique were interview, observation and documents related to the study. Data analysis techniques in the study conducted qualitatively. The results of this study explained that the implementation of E-Government in the field of public services of government offices has been quite effective. It is measured based on indicators measuring the effectiveness according to Gibson.
\end{abstract}

\section{Introduction}

One of the tasks of government is to provide good service to the public as regulated in Law No. 25 of 2009 on Public Service. One effort that can be made in connection with such an objective can optimize the use of Information and Communication Technology [1-2].

Advances in information technology provides maximum benefits to people's lives. Of course, in this globalized world, technological progress is needed and utilized in all fields. One area that is exposed to the touch is the information technology government services to the public [3-5].

Government management system for a hierarchy of authority and command system of sectoral conical and long. To satisfy the needs of an increasingly diverse community in the future should be developed a modern management system with networked organization so as to shorten the lines of decision-making and expand the control range. Therefore, in the era of regional autonomy to make government good governance one of the efforts is to use information and communication technology or popularly called e-Government [6-9].

In Indonesia towards e-Government initiatives have been introduced since 2001 through Presidential Instruction No. 6 of 2001 on Telematics (Telecommunications, Media and Information Technology), which states that government

Revised Manuscript Received on July 05, 2019.

Retno Fuji Oktaviani,

Faculty of Economics and Business Universitas Budi Luhur, Jakarta,

Indonesia, retno.fujioktaviani@budiluhur.ac.id. officials should use telematics technology to support good governance and accelerate the democratic process. Then the release of Presidential Instruction NO. 3 of 2003 on National Policy and Strategy Development of eGovernment is evidence of Indonesian government's commitment to improve the quality of services through electronic government itself [10-11].

Relative to the Governor of Jakarta several periods and has been running this build Jakarta Smart City program that aims to encourage the maximization of Information Technology for achieving good governance [12].

Jakarta Smart City or in common parlance is known as e-Government is a government effort to develop a system of government that is effective, efficient, and transparent to optimize the use of Information Technology systems. This system has evolved since the early 1980s in the developed countries of Europe and Japan, while for the new entry Indonesia in the early 2000s [13].

\section{Literature Review}

\subsection{Effectiveness}

According to Steers (in Sutrisno, 2011), generally only associated with the effectiveness of the organization's objectives, namely profit, which tend to ignore the most important aspect of the overall process, ie human resources. Indrawijaya (2010) effectiveness can be defined as the level of achievement of the organization on short-term goals (objectives) and long term (way). The elections reflect the strategic constituencies, interests evaluate, and the level of organizational life. Effectiveness relates to the execution of a job, the job completion just in time has been set. This means that if the execution of a task is favorable or not, especially the question of how to implement them, and how the costs for it. Explicitly, Robbins suggests four approaches in looking at the effectiveness of an organization.

Goal Attainment approach, approach recognizes that the effectiveness of an organization must be assessed in relation to the achievement of objectives (ends) rather than how (means) as to maximize profit. The achievement of the objectives set, it means there has been a process of change and behavioral change.

System approach, organizations gain input, transformation process, and produce output (output). It has been explained that setting the size of the effectiveness of the approach prganisasi only on the basis of achieving

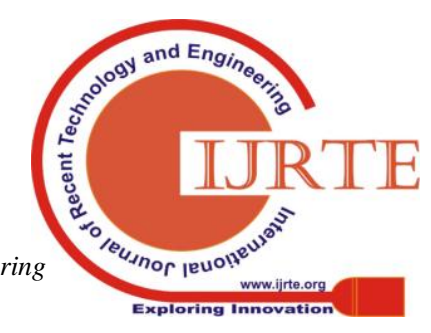


goals, an imperfect measure. With just a result pencapian purpose, means the focus is only on output alone. An organization should also be judged by its ability to obtain input, process the input, output channel, and maintain stability and balance through a systems approach. With the operation of the system, it means there has been a process of change and behavioral change. The systems approach to the effectiveness of the organization implies that the organization is made up of sub-sections interconnected. If one sub-section has a poor performance, then there will be a negative impact on the performance of the whole system.

Strategic-constituencies-approach, this approach suggests that the organization is said to be effective if it meets the demands of constituents contained in the organizational environment that kelanjuatan constituency supporting the existence of the organization. This approach is similar to the view of the system but the emphasis is different. Both take into account the interdependence, but the views of the constituency-positioned not pay attention to all the organizational environment. This view only meet the demands of the things in the organization. This view only meet the demands of the things in the environment that could threaten the survival of the organization. With the process of change and behavioral change. Constituencylooking strategic approach in different organizations. Organization assumed a political arena where groups concerned (vasted interests) vying for control of resources. An organization has a number of constituencies with different levels of power, and each tries to meet their needs. However, each constituency also has a unique set of values, so that their preferences may not be appropriate.

Competing values approach, this approach offers a framework of a more integrative and more varied, because the criteria are selected and used depending on the position and interests of each within an organization. The values of real competition go further than just the recognition of the existence of a diverse selection. Such an approach assumes that the various options that can be consolidated and organized. Competing values approach says that there are common elements that underlie each list a comprehensive organizational effectiveness criteria and that these elements can be combined in such a way so as to create a base set of values compete. Each of the collection, forming a unique model of effectiveness.

\subsection{E-Government}

World Bank defines e-government as follows: EGovernment Refers to the use by government agencies of information technologies (such as Wide Area Networks, the Internet, and mobile computing) that have the ability to transform relations with citizens, businesses, and other arms of government.

According to the UNDP (United Nations Development Program) in Indrajit (2002) E-Government is the applicaton of Information and communicat-ion Technology (ICT) by government agencies. While Janet Caldow, Director of the Institute for Electronic Government (IBM Corporation) in Indrajit (2002) provides a definition of interest, namely Electronic government is nothing short of a fundamental transformation of government and governance at the scale fulfillment of these demands, it means there has been a

we have not witnessed since the beginning of the industrial era.

The benefits obtained with the implementation of egovernment concept for a country, such as: Improving the quality of government services to its stakeholders (communities, businesses, industry), especially in terms of performance effectiveness and efficiency in various fields of life of the state; Improve transparency, control and accountability of governance in order to implement the concept of good corporate governance; Significantly reducing the total cost of adinistrasi, relationships, and interaction of government and stakeholdenya issued for the purposes of everyday activities; Provide an opportunity for the government to mendapatlan new revenue sources through its interaction with third-pihajk concerned; and Creating new communities appropriately can answer various problems encountered in line with the various global changes and trends that exist; and Empowering communities and other parties as a government partner in the process of policy-making in nerata and democratic public. Judging from history, the concept of developing eGovernment for their three (3) main trigger, namely:

1. The era of globalization that comes sooner than expected have made issues such as democratization, human rights, law, transparency, corruption, civil society, good corporate governance, free trade, open markets, and so become the main things that must considered by every nation if those concerned do not want alienated from the social world. In this format the government should hold a repositioning of the role in a country, of which is internal and focused on domestic demand, become more externally oriented and focused on how to position people and his country in a global society

2. Advances in information technology (computer and telecommunications) occurring so rapidly that the data, information and knowledge can be created with very, very fast and can quickly spread to all walks of life in various parts of the world in a matter of seconds. This means that every individual in various countries around the world can communicate directly to anyone who dikegendaki without required intermediary (mediation) whatsoever.

3. Increasing the quality of life of people in the world is inseparable from the improvement in the performance of private industry in conducting economic activities. Intimacy between people (as customers) by economic actors (traders, investors, corporations, and others) have made the establishment of a standard of service that is getting better over time. Acceleration performance improvement in the private sector is not followed with the same acceleration in the public sector, so that people can see the disparity in the standard of quality of service delivery.

\subsection{E-government Public Service}

E-government public service is a system application that can be used for transaction processing and monitoring the creation of documents that exist in government. The egovernment public services intended for the regional administration in managing the administration of 
demographic data. With e-government administrative records and data collection for the referral letter, certificate, cover letter, and so forth can be made electronically which data is stored safely and completely.

The benefits of e-government public services, namely: efficiency and effectiveness in the management of IT-based administration, with data storage in a highly secure Telkom. Increasing productivity in the work, due to the help of IT tools that are very easy to operate without having to provide IT personnel in local government offices. Application of Cloud Computing in government offices, appropriate will improve service quality. Application of Software System in accordance with the Standards of Population Administration will improve the accuracy of population data.

The effectiveness of an organization can be seen whether the execution of a task is favorable or not, the completion of work on at a predetermined time or vice versa, and so on. There are many criteria or indicators that can be used to measure effectiveness. To make it easier to understand the problems studied, it can be used the criteria for the effectiveness of the organization according to Gibson, namely: Production as a criterion of effectiveness refers to the size of the organization's main outputs. The size of the production includes profits, sales, market share, the document is processed, served partner, and so on. This size is directly related to that consumed by customers and partners that organization; Efficiency as a criterion of effectiveness refers to the size of the use of scarce resources by the organization. Efficiency is the ratio between output and input. Efficiency measures consisting of profits and capital, the cost per unit, waste, spare time, the cost per person, and so on. Efficiency is measured by the ratio of profit to cost or time spent; Satisfaction as a criterion of effectiveness refers to the organization's success in meeting the needs of the employee members. Measure of satisfaction include employee attitudes, replacing employees, absenteeism, slackness, complaints, welfare, and so on; Keadaptasian as a criterion of effectiveness refers to the organization in response to external and internal changes. External changes such as competition, the desire of customers, product quality and so on, as well as internal changes such as inefficiency, unsatisfactory, and so an adaptation to the environment; Viability as a criterion of effectiveness refers to the responsibility of the organization / company in expanding the capacity and potential to develop.
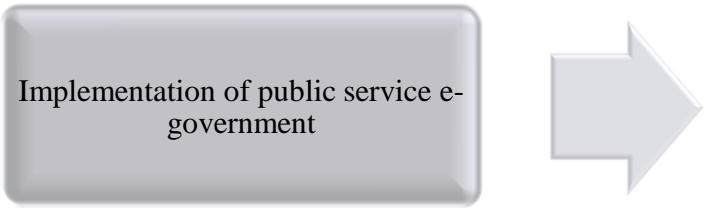

Measuring criteria for

effectiveness According to Gibson:

Production

Efficiency

Satisfaction

Adaptability

Life sustainability

Figure 1. Effectiveness Measurement Criteria

\section{Research Methodology}

In this study the application of e-government public services at local government offices Jakarta, the author uses quantitative and qualitative approach which is descriptive study that provides an overview and explanation of the problems encountered.

Analysis of the data in quantitative and qualitative research, carried out at the time of data collection takes place, and after the completion of data collection in a particular period. At the time of the interview, researchers have conducted an analysis of the answers were interviewed. If the answer were interviewed after the analysis was not satisfactory, the researchers will continue the questions again, to a certain extent, the data obtained are considered credible. Steps are done collecting data analysis after that;

Data Reduction, Reduce data means summarize, choosing the subject matters, focusing on things that are important, look for themes and patterns. Thus the reduced data will provide a clearer picture, and facilitate researchers to conduct further data collection, and look for it when necessary.
Data Display, Once the data is reduced, then the next step is mendisplaykan data. In qualitative research, data presentation can be done in the form of a brief description, chart, relations between categories, flowcharts, and the like. But most often used to present data in qualitative research is the narrative text. With mendisplaykan the data, it will be easier to understand what is happening, to plan further work based on what has been understood that.

Conclusion Drawing / verification, The next step in the analysis of qualitative data is the conclusion and verification. Initial conclusions presented are still provisional, and will change if no strong evidence to support the next stage of data collection. But if the conclusions put forward in the early stages, supported by evidence of valid and consistent when researchers returned to the field to collect data, the conclusions expressed a credible conclusion.

\subsection{Research Result}

SEM test the feasibility of the model with 2 stages commonly called two steps SEM process. The first stage is to test the measurement model, and the second stage

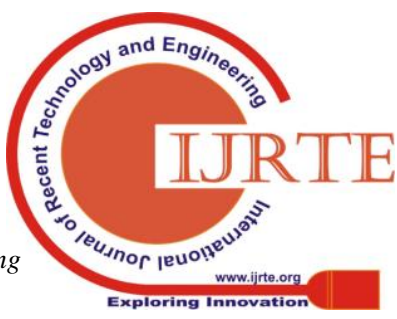


is to test the structural model. Structural model test is used latent variables that exist in the proposed model.

to determine whether there is a relationship between the

Table 1. Test Goodness of Fit

\begin{tabular}{|l|l|r|l|}
\hline criteria & standart & Estimate Result & Match Level \\
\hline Normed Chi-Square (X2 / df) & $<2$ & 1.93 & Good Fit \\
\hline RMSEA & $<0: 08$ & $0: 07$ & Good Fit \\
\hline NFI & $>0.9$ & 0.91 & Good Fit \\
\hline NNFI & $>0.9$ & 0.93 & Good Fit \\
\hline CFI & $>0.9$ & 0.97 & Good Fit \\
\hline GFI & $>0.9$ & 0.93 & Good Fit \\
\hline standarized RMR & $<0: 05$ & 0051 & marginal Fit \\
\hline
\end{tabular}

The results of goodness of fit test on measurement models show that the normed chi-square value, RMSEA, NFI, NNFI, GFI and
CFI meet the criteria of the standard. So the research model fit for use.

Table 2. Hypothesis

\begin{tabular}{|l|r|r|l|}
\hline hypothesis & \multicolumn{2}{|l|}{ estimates } & \multicolumn{2}{|l|}{ Value-t } & Result \\
\hline PRD-> EFK & 0.61 & $5: 08$ & significant \\
\hline EFC-> EFK & $0: 55$ & 4.80 & significant \\
\hline STS-> EFK & 0.70 & $6: 01$ & significant \\
\hline ADP-> EFK & 0.75 & $6: 39$ & significant \\
\hline LFC-> EFK & 0.68 & $5: 32$ & significant \\
\hline
\end{tabular}

He revealed that:

From the test results, there are three relationships of structural models that have a significant influence is PRD-> EFK, EFC-> EFK, STS-> EFK, ADP-> EFK, LFC-> EFK. So it can be concluded that all the factors have a significant influence.

To determine the effectiveness of the implementation of e-government public services, researchers used an indicator measuring the effectiveness by Gibson to make it easier to understand the problems studied. Indicators measuring the effectiveness and Gibson said that the production, efficiency, satisfaction, keadaptasian, and survival. The things mentioned above will be analyzed based on interviews of researchers as further described.

\subsection{Production}

Production of the researchers mean the maximum service provided government offices after using egovernment. Production undertaken by the Office of governments in implementing e-government public services are described in the interview with the author of the Section Head of Governance, Peace and Public Order Mr Rasidin He explained that:

"So far the data related concretely how many societies have felt the complaints of the e-government program, we do not recap, clear about any of our service through e-government public services. These products are issued by e-government public services ranging from settlement services, such as KTP,

KK, Certificate of Move, Domicile. Then on the welfare of the people is a statement of poverty, wills, certificates and much more effort. "

Things are different in a society dictated by Mrs. Rita.
"I think the e-government program that actually aims to facilitate service to the community, but I am as people feel between service user with e-government. Every community should have been able to apply for any kind without having to work, but I feel as a society have not been too many changes ".

Based on interviews with several sources of researchers and production data mentioned above, the researchers concluded that the e-government program has so far been running well although there are still many people who do not know.

\subsection{Efficiency}

The efficiency of the researchers mean any service done through e-government can be a timely and cost savings than if done manually. Here is a recent interview with the Head of Section investigators Government, Public Peace and Order.

"Related austerity budget, almost $70 \%$ of the comparison of before and after using e-government applications. Because if there is a mistake we can directly correction in the application. If the time savings, faster after using e-government public services. Only the name is also e-government public services to use the network so maybe he's got a few weaknesses if there are network interruptions $"$.

Something similar was delivered by one of Sprott society:

"Usually before their new service system, it took at least half an hour to wait for the completion of a letter, but this time enough 10 to 15 minutes then mail has been finished".

Based on the results of research interviews with sources is concerned, it can be concluded that the e-government program of public services if the value of the degree of inefficiency of the already efficient. 


\subsection{Satisfaction}

Satisfaction of the researchers mean is whether the community is satisfied with the service after using egovernment employee. Here is a recent interview with the Head of Section investigators Government, Public Peace and Order.

"The public response is very good, very positive because he felt served optimally and quickly. If the complaint yes because their tissue disorders ".

Something similar was delivered by one of the people named Basuki:

"I just know this program, but I am quite satisfied with the services provided by local government. Although today we have to come to the office first and can be served using computers but in the future I hope we've been able to have their own username and password in order to make the request in the home Based on the interview mentioned above, the researchers concluded that people are quite satisfied with the services provided employees use egovernment program of public service.

\subsection{Adaptation}

External changes such as competition, the desire of customers, product quality and so on, as well as internal changes such as inefficiency, unsatisfactory, and so an adaptation to the environment. Here is a recent interview with the head of the regional government researchers:

"So we are also somewhat constrained by the application of this Program is carried out. But that obstacle can be overcome by training organized by the city government. With training, the employees can apply this program properly and smoothly".

Based on the above results of these interviews, the researcher can conclude that employees are able to adapt to the e-government program based public service first, since most employees have been trained use of e-government.

\subsection{Life sustainability}

The survival of the researchers mean how e-government program can continue to survive in order to help the public service. Here is a recent interview with the Head of Section investigators Government, Public Peace and Order:

"Our hope kedepaannya sebagaipegawai local government, this program can be run as it should or can continue to follow the changing times in modern erea, target semaik service to the community so good and satisfying. Hopefully this program can work well and people can be served with a time-efficient and cost-effective ".

Based on the interview mentioned above, the researchers concluded that the e-government program will survive if there is a strong will of the employees and the community to continue to use it.

\section{CONCLUSION}

From several discussions and a series of results of the analysis that has been done can be concluded, that the implementation of e-government public services at local government offices in the measure in terms of the effectiveness of using criteria measuring the effectiveness by Gibson namely Production, Efficiency, Satisfaction, Keadaptasian and Survival have enough effective. This is evidenced by the fulfillment of the above mentioned indicators, this time the service provided is sufficient maximum employee after their e-government public services. In addition the service processed through the egovernment to save time and cost when compared to manual. People who get service quite satisfied with the implementation of this program. Local government officials can adapt to these IT-based program, and this program can get more leverage in the future again.

Ethical clearance - Not required

Source of funding- Self

\section{Conflict of Interest - Nil}

\section{References}

[1] Achmad, Badu. et al. Course modules. 2013. Electronic Government (e-Govt). Makassar: Hasanuddin University.

[2] Chatab, Nevizond. 2007. Profile Culture Organization. Bandung: Alfabeta.

[3] Darsono \& Siswandoko, Tjatjuk. 2011. Human Resources 21st Century Jakarta: Nusantara Consulting.

[4] Indrajit, Richardus Eko. 2002. Electronic Government Yogyakarta: Andi.

[5] Indrawijaya, Adam Ibrahim. 2010. Theory, Organizational Behavior and Culture. Bandung: Refika Aditama.

[6] Presidential Instruction No. 6 of 2001 on Telematics (Telecommunications,

[7] Media and Information)

[8] Presidential Instruction No. 3 of 2003 on National Policy and Strategy Development of e-Government

[9] Pasolong, Harbani. 2012. Methods of Research Administration. Bandung: Alfabeta.

[10] Sedarmayanti. 2001. Human Resources and Labor Productivity. Bandung: Mandar Maju.

[11] Sugiyono. 2013. Qualitative and Quantitative Research Methods R \& D. Bandung: Alfabeta.

[12] Sutrisno, Edy. 2011. Organizational Culture. Jakarta: Kencana.isẹp]

[13] Tika, Moh. Pabundu. 2008. Organizational Culture and Performance Improvement Company. Jakarta: Earth Literacy. 